\title{
The Study of Entrepreneurial Intentions and Entrepreneurial Competencies of Business vs. Non-Business Students
}

\section{- Tanja Zdolsek Draksler, Karin Sirec}

\begin{abstract}
Entrepreneurship contributes to economic growth and job creation and thus to competitiveness. Nevertheless, the question remains of how to stimulate entrepreneurial activity, especially in the case of youth as a disadvantaged group. The key to entrepreneurial activity is entrepreneurial competencies and entrepreneurial intentions. Young people can acquire and develop both through entrepreneurship education. The aim of this study was to examine the impact of entrepreneurship education on entrepreneurial intentions and entrepreneurial competencies of university students in Slovenia from a socio-psychological perspective. A conceptual research model based on Ajzen's Theory of Planned Behavior (TPB) and the competency approach was developed, also applying the assumption that entrepreneurial competencies influence entrepreneurial intentions. The applied research methodology was a quasi-experiment. The research sample of 837 students consisted of an experimental group (involved in entrepreneurship education) and a control group (not involved in entrepreneurship education) examined by a pretest and a post-test. Various statistical analyses were used to determine correlation, comparison, and dependency. Although it was confirmed that the conceptual research model is appropriate and that some of the factors studied do influence entrepreneurial intentions, we could not find a higher level of entrepreneurial intentions or entrepreneurial competencies by students involved in entrepreneurship education. Nevertheless, the conceptual research model has statistically confirmed that the TPB and entrepreneurial competencies are linked. It was also revealed that entrepreneurial competencies partly influence entrepreneurial intentions. This study forms a basis for further research in the field of entrepreneurship education, entrepreneurial intentions and entrepreneurial competencies.
\end{abstract}

Keywords: entrepreneurship education, entrepreneurial intentions, entrepreneurial competencies, tertiary education

JEL Classification: L25, L26

Received: October, 2020

1st Revision: March, 2021

Accepted: March, 2021 


\section{INTRODUCTION}

European countries are promoting entrepreneurship as a priority, as it contributes to economic growth and job creation (Urbano et al., 2019; Lackéus, 2015; Audretsch et al., 2007). The main policy question remains of how to stimulate entrepreneurial activity (Urbano et al., 2019; Godin et al., 2008), especially in the case of youth as a disadvantaged group. As more and more people are involved in tertiary education, while the labour market and the education system are not coordinated, many young graduates do not obtain employment (in the short term). Therefore, graduates should be helped to enter the labour market by guiding and improving their competencies (Schøtt et al., 2015). However, the key to entrepreneurial activity is acquiring appropriate entrepreneurial competencies (hereafter: EC) which would stimulate their entrepreneurial intentions (hereafter: EI). Both EC and EI can be acquired and developed through entrepreneurship education (hereafter: EE) (Bacigalupo et al., 2016).

In their recommendations, the Global Entrepreneurship Monitor (GEM) (Bosma et al., 2020) and the European Commission (2016) note that educational institutions do not equip young people with capabilities that would enable them to seize and take advantage of opportunities. They point to significant discrepancies between the skills required by business/industry and those provided by the education system. They call for improvements concerning the provision of EE by educational institutions. Acs et al. (2009) assume that educated people are better able to recognize entrepreneurial opportunities. Audretsch et al. (2007) also mention the clustering of entrepreneurial activities at universities as a direct consequence of knowledge spillovers.

At the European level, priority areas are youth employment, the promotion of entrepreneurship and EE (European Commission, 2013). However, in Slovenia, EE is only very slowly being integrated into the Slovenian education system. As Slovenia has succeeded in rehabilitating the high unemployment caused by the economic crisis (in 2008) through various labour market reforms, the (long-term) unemployment of young people as one of the most vulnerable social groups remains a problem. At present, the policy of inclusive entrepreneurship in Slovenia aims to improve the employability of young people through various programmes at the national, regional, and local levels.

As previous studies suggest, EE represents developing certain qualities and is not necessarily directly linked to the creation of new companies (Lackéus, 2015). It indicates developing an entrepreneurial mindset (or entrepreneurial thinking) that enables entrepreneurs to turn ideas into action (European Commission, 2013). The key assumption is that EC/skills can be learned since they are not predefined personal characteristics (Bacigalupo et al., 2016; Oosterbeek et al., 2010). Although only a minority of graduates start ambitious enterprises, most young people who have gone through EE could use the acquired entrepreneurial knowledge and skills in many professions and organizations and thus raise the level of expertise and innovation in SMEs and all different types of organizations. For this reason, EE should be accessible to all students in higher education (Rae, 2014). Entrepreneurship is also one of the key competencies for lifelong learning, along with personal initiative (Bacigalupo et al., 2016).

Students in all higher education institutions should be encouraged to develop entrepreneurial skills as part of their study programme obligations. In this way, every student could develop an 
entrepreneurial mindset, experience, and entrepreneurial skills within their studies (Rae, 2014). Curth et al. (2015) note that EE at the student level strengthens professional ambitions, leading to greater employability, improving entrepreneurial skills and entrepreneurial attitudes as well as behavioral changes in the sense of more EI. The authors go even further, noting that EE impacts society as a whole, as it is the element that can help protect individuals from social exclusion.

Our research aims to provide several contributions to behavioral perspectives on entrepreneurship, focusing on the individual as an entrepreneur. We have conducted a quantitative empirical study for the case of Slovenia which examines the influence of EE on EI and EC from a sociopsychological perspective.

This paper is divided into five sections. The introduction is followed by the theoretical background and the literature review of EI and EC, which led to the development of a conceptual research model. The third section explains the research objective, methodology and data. In the fourth section, the results are described and discussed. Section five presents the conclusion.

\section{THEORETICAL BACKGROUND}

When EE is mentioned, two important goals can be outlined, namely the acquisition of EC and positive EI.

\subsection{Entrepreneurial intentions (EI)}

Social psychological theories and models in entrepreneurship research began in the 1990s (van Gelderen et al., 2008). The Theory of Planned Behavior (hereafter TPB) (Ajzen, 2005) is the most commonly used model, with strong statistical support (Lackéus, 2015) that attempts to explain the relationship between an individual's characteristics and his EI (Ajzen, 2005). Based on the literature review (Cera et al., 2020; Roy et al., 2017; Serida Nishimura \& Morales Tristán, 2011; van Gelderen et al., 2008; Souitaris et al., 2007; Veciana et al., 2005), we decided to base the research on Ajzen's TPB, which is recognized as the best known in the field of social psychology (Liñán \& Fayolle, 2015).

Most studies dealing with the effects of EE assume that entrepreneurship is a consciously planned behavior. The link between personal views, intentions and behavior is used (Lackéus, 2015). Intentions are known to be the best predictor of planned behavior (Ajzen, 2005; Marques et al., 2012).

In TPB, the individual's intentions are influenced by several factors, i.e. attitude towards entrepreneurship (TPB_ATE), subjective norms (TPB_SN), and perceived behavioral control (TPB_PBC), on which the individual's reactions, i.e. his behavior, depend. Ajzen's model attempts to clarify the relationship between the personal characteristics of an individual and his EI (TPB_EI) (Ajzen, 2005).

Starting from the theory, the hypotheses H1-H6 were formed:

H1: The attitude towards entrepreneurship (TPB_ATE) has a positive influence on student EI (TPB_EI). 
H2: Subjective norms (TPB_SN) about entrepreneurship have a positive influence on student EI (TPB_EI).

H3: Perceived behavioral control (TPB_PBC) concerning entrepreneurship has a positive influence on student EI (TPB_EI).

H4: Subjective norms (TPB_SN) influence student attitudes towards entrepreneurship (TPB_ ATE).

H5: Subjective norms (TPB_SN) influence students' perceived behavioral control (TPB_PBC).

H6: EE has a positive influence on students' EI.

The studies that confirmed EE's impact on EI include Cera et al. (2020), Sánchez (2011). Conversely, there are also studies that have refuted the influence of EE on EI (Oosterbeek et al., 2010; Von Graevenitz et al., 2010; Volery et al., 2013).

\subsection{Entrepreneurial competencies (EC)}

Some researchers claim that EC is necessary to start a business, whereas the development of a business requires managerial competencies. Others point out that entrepreneurship requires competencies in both areas. EC is defined as the general ability of an entrepreneur to perform work (Man et al., 2012). On the other hand, the authors agree that the entrepreneurial context focuses on the individual, while the management context focuses on the organisation (Mitchelmore \& Rowley, 2010). Bird (2019) argued that competencies are related to entrepreneurial behavior and can be learned. The characteristics of an individual, on the other hand, are fixed and defined as inaccessible because we cannot learn them. Factors that can influence EC development and should therefore be considered are education, work experience and entrepreneurial experience (Bird, 2019).

The theory of investigating entrepreneurial behavior is most often divided into focusing on personality traits or the competencies of individuals through the competence approach (Boyatzis, 2011). While the investigation of personality traits is about profiling successful individuals, the competence approach provides the theoretical basis for individuals' competencies. It will be used in this study. Moreover, the competence theory is based on the research of successful leaders and reveals their behavior, attitudes, and abilities and presents them in the form of measurable characteristics. On the other hand, competency theory looks for ways to bring these units together to create individuals who demonstrate superior performance (Mitchelmore and Rowley, 2010).

Izquierdo \& Buyens (2008) confirmed that students had a higher level of EC (in terms of knowledge and skills) after completing EE, but the research included a specific teaching method (constructivism). In the same survey, it was also reported that students with a higher level of EC report a higher level of entrepreneurial self-efficacy (after completing EE). Also, Von Graevenitz et al. (2010) confirmed a positive impact on entrepreneurial skills, which is important because we believe that entrepreneurial skills are also EC.

On the other hand, some studies have neglected EE's effects on EC, namely Oosterbeek et al. (2008). The study looked at skills (creativity, flexibility, market knowledge) and found a negative 
difference for all three skills (in our case, they are competencies); this means a reduced level of the mentioned skills after EE (Oosterbeek et al., 2008). Volery et al. (2013) then similarly asked themselves what influence EE has - they predicted that participation in an EE programme has a positive effect on personality traits, beliefs, knowledge, competencies, and EI. The results showed that EE did not have a significant impact on competencies.

The studies that focused on the relationship between EC and EI (Bonesso et al., 2018; Reyes et al., 2018) confirmed a significant correlation between them.

Starting from the theory, the hypotheses $\mathrm{H} 7$ and $\mathrm{H} 8$ were formed:

H7: EC influences EI positively.

H8: EE has a positive influence on EC.

\subsection{Conceptual research model - linking entrepreneurial intentions and entrepreneurial competencies}

Following the theoretical investigation, a conceptual research model was developed (Figure 1) based on Ajzen's TPB and the competency theory approach. The purpose of this model is to investigate the impact of EE on EI and EC and to investigate whether EC has an impact on EI.

Several EC models (Man, 2012; Lau et al., 2012; Moberg et al., 2014; Kyndt \& Baert, 2015) were combined. Since the individual competencies have in part different names and scopes, they are essentially consistent in terms of content. Since some of the competence constructs of these models overlap (wholly or partially), we have modified them and created a uniform model (Table 1). Theoretical models by Man (2012), Lau et al. (2012), Kyndt \& Baert (2015) have been fully adopted, while the model by Moberg et al. (2014) has been partially adopted. Finally, we received 17 competence constructs (Zdolšek Draksler \& Širec, 2018).

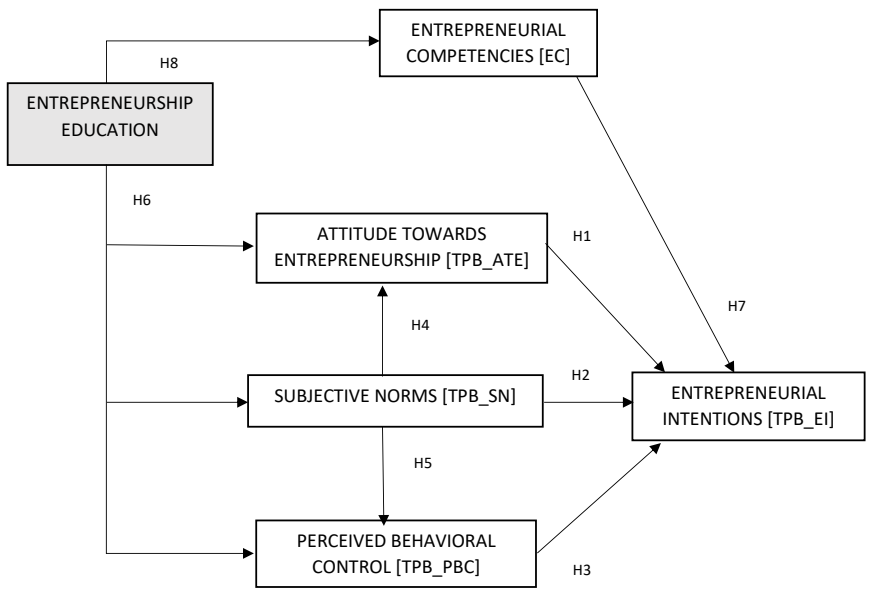

Fig. 1 - Conceptual research model to study the effects of EE on EC and EI. Source: own research 
Tab. 1 - 17 EC constructs. Source: own research

\begin{tabular}{|c|c|c|}
\hline $\begin{array}{l}{\left[\mathrm{EC} \_\mathrm{A}\right] \text { Competencies for }} \\
\text { strategic planning for the } \\
\text { future }\end{array}$ & $\begin{array}{l}\text { [EC_G] Competencies of self-knowl- } \\
\text { edge }\end{array}$ & [EC_M] Independence \\
\hline $\begin{array}{l}\text { [EC_B] Competencies of } \\
\text { decisiveness and commit- } \\
\text { ment }\end{array}$ & $\begin{array}{l}{\left[\mathrm{EC} \_H\right] \text { Sustainable behavior compe- }} \\
\text { tencies }\end{array}$ & $\begin{array}{l}{\left[\mathrm{EC} \_\mathrm{N}\right] \text { Awareness of }} \\
\text { potential returns on } \\
\text { investments }\end{array}$ \\
\hline $\begin{array}{l}{\left[\mathrm{EC} \_\mathrm{C}\right] \text { Conceptual com- }} \\
\text { petencies }\end{array}$ & $\begin{array}{l}\text { [EC_I] Competencies for market } \\
\text { insight }\end{array}$ & [EC_O] Perseverance \\
\hline $\begin{array}{l}{\left[\mathrm{EC} \_\mathrm{D}\right] \text { Organizing com- }} \\
\text { petencies }\end{array}$ & $\begin{array}{l}{\left[E C_{-} J\right] \text { Competencies or recognizing }} \\
\text { opportunities }\end{array}$ & $\begin{array}{l}{[\text { EC_P] Entrepreneur- }} \\
\text { ial knowledge }\end{array}$ \\
\hline $\begin{array}{l}\text { [EC_E] Personal strength } \\
\text { competencies }\end{array}$ & $\begin{array}{l}{\left[\mathrm{EC} \_\mathrm{K}\right] \text { Competencies of building }} \\
\text { networks and relationships }\end{array}$ & [EC_R] Creativity \\
\hline $\begin{array}{l}{\left[\mathrm{EC} \_\mathrm{F}\right] \text { Learning compe- }} \\
\text { tencies }\end{array}$ & [EC_L] Ability to persuade & \\
\hline
\end{tabular}

\section{RESEARCH OBJECTIVE, METHODOLOGY AND DATA}

The aim of the study was to examine the impact of entrepreneurship education on entrepreneurial intentions and entrepreneurial competencies of university students in Slovenia from a sociopsychological perspective. The conceptual research model (Figure 1) was used to study EI and EC. Regarding the statistical methods used, correlation analysis was used for testing dependencies between variables, and regression analysis for testing causal relationships between variables. A pre-test post-test quasi-experimental design was used as the most suitable methodology upon previous research (Sánchez, 2013; Rideout \& Gray, 2013). The research sample consists of the experimental group (business students involved in EE) and the control group (non-business students not involved in EE). The measuring instrument for data collection was a questionnaire consisting of: (1) measurement for TPB (24 items), (2) measurement for EC (99 items). Questionnaires were obtained from the literature and adopted; for the TPB part from Liñán \& Chen (2009), Franke \& Lüthje (2004) and Autio et al. (2001); for the EC part from Kyndt \& Baert (2015), Moberg et al. (2014), Man (2012) and Lau et al. (2012).

The measurement instrument is based on claims designed as behavioral indicators and asks individuals how often they perform certain behaviors on the Likert scale from 1 to 6 . The reliability was confirmed by a pilot study. The possibility of overestimating by individuals (bias) must also be pointed out, as the questions are answered based on individual assessments of themselves. The reliability of the measuring instrument used was confirmed by the Cronbach alpha indicator (the results for all constructs range from 0.712 to 0.925 ).

The research sample consists of students from seven faculties from Slovenia. The pre-test was conducted at the beginning of the academic year, and the post-test at the end of the academic year. The pre-test was carried out when the experimental group was not yet (on a larger scale) involved in EE. The post-test was carried out when the experimental group was already engaged in EE. Based on the data, four groups were generated for further analysis (Table 2). 
Tab. 2 - Generated groups for analysis. Source: own research

\begin{tabular}{|l|l|l|l|}
\hline Group number & Group type & Time & No. of students \\
\hline Group 1 & Experimental group & Pre-test & 194 \\
\hline Group 2 & Experimental group & Post-test & 142 \\
\hline Group 3 & Control group & Pre-test & 289 \\
\hline Group 4 & Control group & Post-test & 212 \\
\hline Research sample together & & 837 \\
\hline
\end{tabular}

\section{RESULTS AND DISCUSSION}

The correlation analysis of the TPB constructs shows a high linear relationship between the constructs TPB_EI, TPB_ATE, and TPB_PBC. For the construct of TPB_SN, a medium relationship to other constructs is valid. The correlations of the TPB constructs are predicted with high probability with $\mathrm{p} \leq 0.01$. The values of the correlation coefficients for EC constructs also show a positive linear relationship between the constructs $(p \leq 0.01)$, which is usually high and medium correlation, but there is also a low correlation.

PCA was used to reduce the variables, the correlation between the variables was determined using the correlation matrix. Keiser-Meyer-Olkin statistics (KMO) and Bartlett's test of sphericity (BTS) were used and yielded 20 factors (all constructs were obtained, the difference is only in EC constructs, where EC_I and EC_J were merged into FAC10). Factors are shown in Table 3.

Tab. 3 - Multiple regression analysis results. Source: own research

\begin{tabular}{|c|c|c|c|c|c|c|c|c|}
\hline 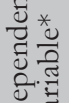 & $\begin{array}{l}\text { Independent } \\
\text { variable* }\end{array}$ & B & $\begin{array}{l}\text { Std. } \\
\text { Error }\end{array}$ & Beta & $\mathrm{t}$ & Sig. & \multicolumn{2}{|c|}{$\begin{array}{l}\text { Collinearity Statis- } \\
\text { tics: Tolerance VIF }\end{array}$} \\
\hline \multirow{7}{*}{ 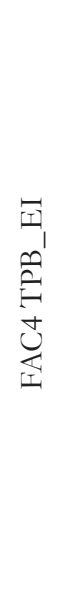 } & $\begin{array}{l}\text { FAC1 } \\
\text { TPB_ATE }\end{array}$ & 0.592 & .028 & 0.591 & 20.916 & 0.000 & 0.566 & 1.768 \\
\hline & $\begin{array}{l}\text { FAC2 TPB_ } \\
\text { SN }\end{array}$ & 0.000 & .026 & 0.000 & 0.018 & 0.985 & 0.691 & 1.447 \\
\hline & $\begin{array}{l}\text { FAC3 } \\
\text { TPB_PBC }\end{array}$ & 0.187 & .032 & 0.187 & 5.831 & 0.000 & 0.438 & 2.281 \\
\hline & $\begin{array}{l}\text { FAC5 } \\
\text { EC_K }\end{array}$ & 0.013 & .022 & 0.013 & 0.582 & 0.561 & 0.896 & 1.116 \\
\hline & FAC6 EC_L & 0.009 & .022 & 0.009 & 0.407 & 0.684 & 0.922 & 1.085 \\
\hline & $\begin{array}{l}\text { FAC7 } \\
\text { EC_D }\end{array}$ & 0.079 & .022 & 0.079 & 3.553 & 0.000 & 0.915 & 1.092 \\
\hline & $\begin{array}{l}\text { FAC8 } \\
\text { EC_O }\end{array}$ & -0.001 & .022 & -0.001 & -0.051 & 0.959 & 0.936 & 1.069 \\
\hline
\end{tabular}




\begin{tabular}{|c|c|c|c|c|c|c|c|c|}
\hline \multirow{12}{*}{ 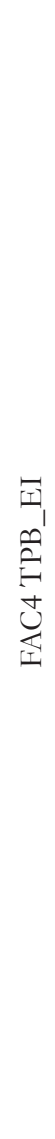 } & $\begin{array}{l}\text { FAC9 } \\
\text { EC_M }\end{array}$ & -0.016 & .022 & -0.015 & -0.716 & 0.474 & 0.967 & 1.034 \\
\hline & $\begin{array}{l}\text { FAC10 } \\
\text { EC_I. } \\
\text { EC_J }\end{array}$ & 0.079 & .023 & 0.080 & 3.511 & 0.000 & 0.873 & 1.146 \\
\hline & $\begin{array}{l}\text { FAC11 } \\
\text { EC_N }\end{array}$ & -0.005 & .022 & -0.005 & -0.234 & 0.815 & 0.962 & 1.039 \\
\hline & $\begin{array}{l}\text { FAC12 } \\
\text { EC_F }\end{array}$ & 0.089 & .022 & 0.089 & 4.140 & 0.000 & 0.975 & 1.025 \\
\hline & $\begin{array}{l}\text { FAC13 } \\
\text { EC_R }\end{array}$ & 0.066 & .023 & 0.066 & 2.875 & 0.004 & 0.864 & 1.158 \\
\hline & $\begin{array}{l}\text { FAC14 } \\
\text { EC_G }\end{array}$ & -0.016 & .022 & -0.016 & -0.734 & 0.463 & 0.974 & 1.026 \\
\hline & $\begin{array}{l}\text { FAC15 } \\
\text { EC_A }\end{array}$ & 0.027 & .022 & 0.027 & 1.245 & 0.213 & 0.952 & 1.050 \\
\hline & $\begin{array}{l}\text { FAC16 } \\
\text { EC_C }\end{array}$ & 0.096 & .023 & 0.097 & 4.265 & 0.000 & 0.878 & 1.139 \\
\hline & $\begin{array}{l}\text { FAC17 } \\
\text { EC-B }\end{array}$ & -0.022 & .022 & -0.022 & -0.975 & 0.330 & 0.903 & 1.108 \\
\hline & $\begin{array}{l}\text { FAC18 } \\
\text { EC-E }\end{array}$ & 0.008 & .022 & 0.008 & 0.375 & 0.708 & 0.945 & 1.058 \\
\hline & $\begin{array}{l}\text { FAC19 } \\
\text { EC_P }\end{array}$ & 0.036 & .024 & 0.036 & 1.492 & 0.136 & 0.780 & 1.282 \\
\hline & $\begin{array}{l}\text { FAC20 } \\
\text { EC_H }\end{array}$ & -0.021 & .022 & -0.021 & -0.986 & 0.325 & 0.976 & 1.024 \\
\hline & \multicolumn{8}{|c|}{$\begin{array}{l}\text { Model: } R=0.831 \text {; Adjusted R-square }=0.683 \text {; Std. Error of the estimate: } 0.5635, F- \\
\text { test: } F=80.645(p<0.001)\end{array}$} \\
\hline
\end{tabular}

*Factors: FAC1-ATTITUDE TOWARDS ENTREPRENEURSHIP [TPB_ATE]; FAC2-SUBJECTIVE NORMS [TPB_SN]; FAC3-PERCEIVED BEHAVIORAL CONTROL [TPB_PBC]; FAC4ENTREPRENEURIAL INTENTIONS [TPB_EI]; FAC5-COMPETENCE OF BUILDING NETWORKS AND RELATIONSHIPS [EC_K]; FAC6-ABILITY TO PERSUADE [EC_L]; FAC7-ORGANIZING COMPETENCE [EC_D]; FAC8-PERSEVERANCE [EC_O]; FAC9-INDEPENDENCE [EC_M]; FAC10COMPETENCE FOR MARKET INSIGHTS AND OF RECOGNIZING OPPORTUNITIES [EC_ I+EC_J]; FAC11-AWARENESS OF POTENTIAL RETURNS ON INVESTMENTS [EC_N]; FAC12LEARNING COMPETENCE [EC_F]; FAC13-CREATIVITY [EC_R]; FAC14-SELF-KNOWLEDGE COMPETENCE [EC_G]; FAC15-COMPETENCE FOR STRATEGIC PLANNING FOR THE FUTURE [EC_A]; FAC16-CONCEPTUAL COMPETENCE [EC_C]; FAC17-COMPETENCE OF DECISIVENESS AND COMMITMENT [EC_B]; FAC18-PERSONAL STRENGTH COMPETENCE [EC_E]; FAC19ENTREPRENEURIAL KNOWLEDGE [EC_P]; FAC20-SUSTAINABLE BEHAVIOR COMPETENCE [EC_H] 
Firstly, the simple regression analysis confirmed the influence (as a direct effect) of the subjective norm factor (TPB_SN) on the attitude toward entrepreneurship factor (TPB_ATE) as well as on the perceived behavioral control factor (TPB_PBC). The simple regression analysis showed that with the influence of the TPB_SN factor, we can explain $12 \%$ of the variability of the dependent variable TPB_ATE. Although the effect is small, it is statistically significant. The value of the regression coefficient for the variable TPB_SN tells us that the dependent variable TPB_ATE increases by 0.348 units, assuming that the variable factor TPB_SN increases by 1 unit. The simple regression analysis showed that TPB_SN factor has a statistically significant effect on the dependent variable TPB_ATE at $\mathrm{p} \leq 0.01$. Furthermore, the simple regression analysis also showed that the influence of the TPB_SN factor explains $13 \%$ of the variability of the dependent variable TPB_PBC. For this reason, the independent variable TPB_SN has a statistically significant impact on the dependent variable TPB_PBC at $\mathrm{p} \leq 0.01$. Again, the influence is small but statistically significant. Secondly, we verified the conceptual research model (as a whole) with multiple regression analysis since we were interested in the direct influence of the factors studied on the EI. The results show that the conceptual research model used is appropriate because it has predictive value. The results of the multiple regression analysis (presented in Table 3) show that the independent variables of the model can well predict the dependent variable entrepreneurial intention (TPB_EI). Based on the values of the determination coefficient (adjusted R2 $=0.683$ ), it was shown that $68.3 \%$ of the variability of the dependent variable can be explained by the variance of the independent variables. F-test (80.645) and statistical significance at $\mathrm{p} \leq 0.01$ confirmed the relationship between the EI (TPB_EI or FAC4) and all independent factors involved. Furthermore, the results of the t-test show that the following factors influence the EI in a statistically significant way: FAC1 TPB_ATE: attitude towards entrepreneurship, FAC3 TPB_PBC: perceived behavioral control, FAC7 EC_D: organization and leadership competence, FAC10 EC_I and EC_J: market insights and opportunities competence, FAC12 EC_F: learning competence, FAC13 EC_R: creativity competence, and FAC16 EC_C: conceptual competence. It is assumed that these have a statistically significant positive effect on the dependent variable entrepreneurial intention (FAC1 TPB_EI). The highest regression coefficient has the factor FAC1 (TPB_ATE), from which we conclude that the dependent entrepreneurial intention variable changes by 0.592 units when the independent variable FAC1 (TPB_ATE) is changed. We were also curious about which independent variable has the most significant influence on the dependent variable, so we compared the values of the standardized coefficients (Beta). Since the standardized coefficient of the independent variable TPB_ATE (FAC1) has the highest value, we can conclude that the mentioned factor also has the most significant influence on the dependent variable EI. Moreover, the Tolerance statistic and the VIF values do not show multicollinearity symptoms. Next, the assumption checked is the verification of error term and homoscedasticity. The P-P plot and the scatterplot (Figure 2) show a normal distribution of residual and positive homoscedasticity. 

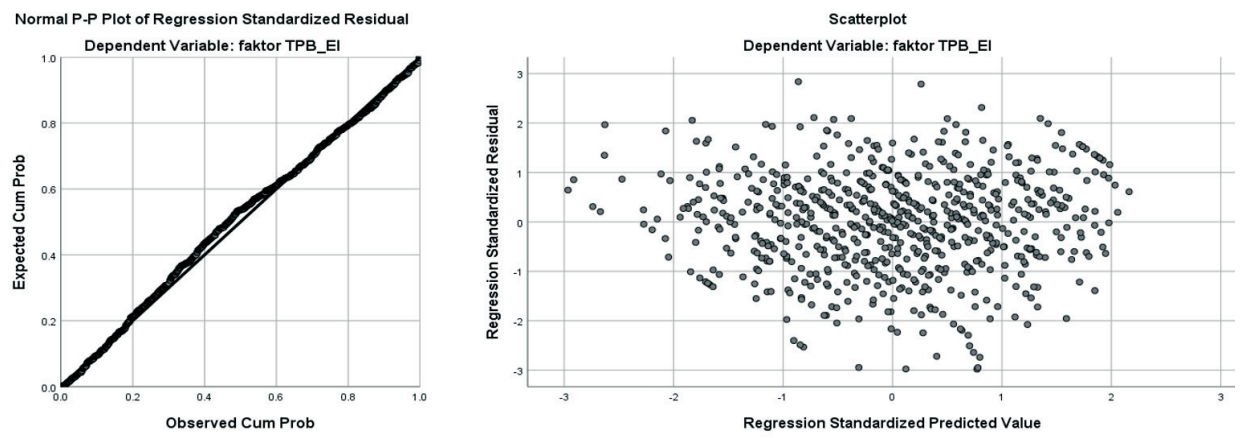

Fig. 2 - Normal P-P plot (left). Scatterplot (right). Source: own research

In summary, the result is favourable concerning the TPB factors since TPB_ATE (attitude towards entrepreneurship) and TPB_PBC (perceived behavioral control) have a significant influence on EI. Only the factor TPB_SN (subjective norms) has no impact. Regarding the EC factors, the result is surprising, since of a total of sixteen factors only five factors of entrepreneurial competence (FAC7: organization and leadership competence, FAC10: market insight and opportunity recognition competence, FAC12: learning competence, FAC13: creativity competence and FAC16: conceptual competence) have a statistically significant influence on the EI.

\subsection{Discussion}

Based on the results described above, $\mathrm{H} 1$, which states that the attitude towards entrepreneurship (TPB_ATE) has a positive influence on the students' EI (TPB_EI), can be accepted. The multiple regression analysis showed that the independent variable TPB_ATE (attitude towards entrepreneurship) has a statistically significant positive effect on the dependent variable TPB_EI (entrepreneurial intentions). The factor TPB_ATE is reflected in the favourable or unfavourable assessment of a particular behavior by a person (Ajzen, 2005). In our case, it is the positive or negative evaluation of students whether they become entrepreneurs. Our results are consistent with many previous studies (Souitaris et al., 2007; Liñán \& Chen, 2009; Marques et al., 2012; Fretschner \& Weber, 2013; Küttim et al., 2014; Sampedro et al., 2014).

Next, H2 should be rejected, which states that subjective norms (TPB_SN) about entrepreneurship have a positive influence on the students' EI (TPB_EI). We could not confirm a statistically significant effect of the factor TPB_SN (subjective norms) on the EI. Subjective norms in entrepreneurship refer to social norms and perceived pressure from the environment; both influence entrepreneurial behavior. Subjective norms are linked to students' perceptions of what important people would think about entering or starting a business (Veciana et al., 2005). Among the TPB factors, the TPB_SN factor is the one for which the least agreement and unity is found according to the scientific literature studied. Examples of empirical studies that confirm the influence of the TPB_SN factor on the EI are Souitaris et al. (2007) and Fretschner \& Weber (2013), while examples of studies that reject the influence are Liñán \& Chen (2009), Serida Nishimura \& Morales Tristán (2011), Küttim et al. (2014). 
Furthermore, $\mathrm{H} 3$ can be accepted with the assertion that the perceived behavioral control (TPB_ PBC) in relation to entrepreneurship has a positive influence on the student's EI (TPB_EI). Multiple regression analysis showed that the factor TPB_PBC has a statistically significant impact on the dependent variable TPB_EI. The TPB_PBC factor refers to the ease or difficulty of a particular behavior. It is also assumed to be a factor that expresses experiences and potential barriers (Ajzen, 2005). It could therefore be defined as a criterion for the ability to behave entrepreneurially. The influence of the TPB_PBC factor on the EI has also been confirmed by previous studies, e.g. Sampedro et al. (2014), Küttim et al. (2014), Serida Nishimura \& Morales Tristán (2011), Liñán \& Chen (2009).

Also, H4 can be accepted, claiming that subjective norms (TPB_SN) influence students' attitudes towards entrepreneurship (TPB_ATE). The simple regression analysis showed that the factor TPB_SN has a statistically significant influence on the dependent variable TPB_ATE. The influence factor indicates the influence of persons, e.g. teachers, parents, friends, relatives, on the student's decisions and thus on his or her attitude towards entrepreneurship. The influence of EE and the influence of closely associated self-employed persons is essential and relevant. Non-formal EE should also be mentioned as a form of activity to achieve impact (events in technology parks, incubators, etc.). Next, role models can also influence young people. It is worth mentioning that some authors have refrained from research on the impact of TPB_SN on TPB_ATE and TPB_PBC (Serida Nishimura \& Morales Tristán, 2011), and have only studied the direct influence of the factor TPB_SN on TPB_EI (entrepreneurial intentions). We decided to devote some attention to the factor TPB_SN and its influence on TPB_ATE and TPB_PBC, as this was also the approach taken by the authors Liñán \& Chen (2009), Heuer \& Liñán (2013), Fretschner \& Weber (2013), Sampedro et al. (2014), who all confirmed the influence of the factor TPB_SN on TPB_ATE.

The following H5, which states that subjective norms (TPB_SN) influence the perceived behavioral control of students (TPB_PBC), can be accepted. Simple regression analysis confirmed the influence of TPB_SN on the dependent variable TPB_PBC. The impact of the factor TPB_SN on the factor TPB_PBC was also confirmed by Liñán \& Chen (2009), whereas it was not confirmed by Fretschner \& Weber (2013). The influence of the TPB_SN factor on the TPB_PBC factor is a positive encouragement from the environment, which can help students to increase their self-esteem and consequently decide to become entrepreneurs (Lo, 2011). In general, EE is undoubtedly a positive incentive for entrepreneurship. On the other hand, EE also represents the entrepreneurial environment within the university.

With the claim that EE has a positive influence on the students' EI, H6 can be partially accepted, since EE does not directly influence student EI but does influence the factors TPB_ATE (attitude towards entrepreneurship) and TPB_PBC (perceived behavioral control). Comparing the experimental group vs. control group with the t-test served to compare the mean values of the two samples. We determined whether there were statistically significant differences between the groups concerning TPB constructs. We investigated the relationship between group 1 (experimental group at the time of pre-test) and group 2 (experimental group at the time of post-test) - the same study group in different periods (before and after the influence of EE), thus we were able to predict a difference in all TPB constructs. Surprisingly, the results 
show a difference concerning the mean, namely a decrease, in the construct TPB_ATE (attitude towards entrepreneurship) and the construct TPB_EI (entrepreneurial intentions). In contrast, the mean value analysis shows an increase in the construct TPB_SN (subjective norms) and the construct TPB_PBC (perceived behavioral control). Given the statistical significance, the difference between groups 1 and 2 in the constructs TPB_ATE and TPB_PBC can be confirmed. The difference in the constructs TPB_EI (entrepreneurial intentions) and TPB_SN (subjective norms) is not statistically significant. EE has a statistically significant influence on the factor TPB_ATE (attitudes towards entrepreneurship) and the factor TPB_PBC (perceived behavior control). It is assumed that both factors influence the EI. Thus we can conclude that the influence of EE on entrepreneurial intentions via the factors TPB_ATE and TPB_PBC is present as an indirect influence.

The TPB_ATE factor (attitude towards entrepreneurship) tells us whether a person will evaluate the entrepreneurial path positively or negatively. In this case, therefore, the attitude towards entrepreneurship has decreased due to increased knowledge of the necessary input for entrepreneurship, the state of the business infrastructure, and the risks of self-employment. There is also a statistically significant difference in the construct TPB_PBC (perceived behavioral control), which refers to the simplicity or difficulty of a particular behavior. According to the results, students assessed that they could become entrepreneurial, which we consider a positive impact of EE.

We also investigated the relationship between group 3 (control group on pre-test) and group 4 (control group on post-test). For the control group at different points in time, we could not predict any difference in any TPB construct. Surprisingly, the mean values for all observed variables are higher in group 4, which suggests that after a specific period, students in the control group also begin to estimate entrepreneurship, as evidenced by all TPB factors. However, a statistically significant difference between group 3 and group 4 is only seen in the TPB_PBC construct (perceived behavioral control). Other changes are not statistically significant. This result is surprising since the control group was not exposed to EE. It can be assumed that the change was influenced by another factor during the general education process or that changes in the environment may have led to a changed perception of business opportunities.

Studies by authors who have refuted the influence of EE on EI include Volery et al. (2013), Oosterbeek et al. (2010), and Von Graevenitz et al. (2010). An example of a study that confirms the opposite in the same way as our research is a study by Souitaris et al. (2007).

Next, H7, which claims that EC positively influences EI, can be partially confirmed. Based on multiple regression analysis, we found that entrepreneurial competencies in only five constructs of entrepreneurial competencies (organizational and leadership competence (FAC7), market insights and opportunity recognition competence (FAC10), learning competence (FAC12), creativity competence (FAC13), and conceptual competence (FAC16)) have a statistically significant influence on student EI, which is surprising. In their empirical research, Volery et al. (2013) refute the influence of EC on EI. In contrast to the present study, their research did not concern the constructs of EC, but examined only two competencies, namely the opportunity recognition competence and the opportunity utilization competence. The authors concluded that it is necessary to design entrepreneurial competencies that students should acquire via EE 
and evaluate them (Volery et al., 2013). We have responded to this need with our EC model. There is a lack of empirical research investigating the link between EC and EI (Kyndt \& Baert, 2015; Sánchez, 2011), and our study fills this gap.

Finally, H8, which states that EE has a positive influence on EC, must be rejected. Based on a t-test, it was found that EE does not affect the students' entrepreneurial competencies. We investigated the relationship between group 1 (experimental group in pre-test) and group 2 (experimental group in post-test). A difference in all EC constructs was predicted, but the results showed no statistically significant difference, which is an unexpected result. We can assume that this is a consequence of different constraints, e.g. a short measurement gap. A longer-term study might confirm the positive difference between the two experimental groups analysed. Therefore, we believe that it is reasonable to investigate the influence of EE on EC.

Concerning the comparison of group 1 (experimental group at the pre-test) and group 3 (control group at the pre-test), no differences were expected, as both groups were defined by the outset of the initial situation. Nevertheless, there was a statistically significant difference in four constructs of EC: namely EC_A (competence for strategic planning for the future), EC_D (organizational and leadership competence), EC_N (awareness of potential returns on investment) and EC_P (entrepreneurial knowledge). This result could be explained in such a way that several factors influence students' EI, not only EE; one of these factors might be general education in different forms (formal or informal).

\section{CONCLUSION}

Within the scope of this research, we empirically tested to determine whether EE influences the EI and EC of students and whether EC influences student EI. Although we confirmed that the conceptual research model used is appropriate and that some of the variables studied influence the EI, students did not perceive a higher degree of EI and EC, although they were involved in EE within formal higher education in Slovenia. The main result is that EE within formal higher education partly influences EI, but not students' EC. EE has a partial influence on students' EI, as EE does not directly influence the students' EI. Still, it influences the variable attitudes towards entrepreneurship and the variable of perceived behavioral control (for both, a statistically significant effect on the EI was confirmed). Some pronounced differences between business students and students of non-business study orientations have been identified. The impact of EE on EC was not confirmed. On the other hand, the research results confirmed that $\mathrm{EC}$ has a positive influence on EI.

In general, there is very little empirical research investigating the link between EC and EI. Therefore, our research is of utmost importance, with the section exploring the influence of EC on EI (despite the observation that EC only partially - within six constructs - influences EI) representing the basis for further research.

Undoubtedly, it would be urgently necessary to replicate the study and at the same time change the time frame for the measurement - this should be longer, e.g. before and after completion of the study. Nevertheless, the research results obtained can be generalized to the whole population, and therefore this research may serve as the basis for further research in EE, EI, and EC. 
Finally, we address the limitations of our study. First, since the data are based on the selfassessments of individuals (students), there is a possibility of overestimation (bias). Secondly, not all faculties in Slovenia participated in the study. Thirdly, we did not analyse the exact same group of respondents in the survey in the pre- and post-measurement stages. Namely, our identification number was not the ID number of the student who participated in the survey, but the number of the study program (faculty/study program/year).

There are many opportunities for further research. Since the research topics are very complex, it is possible to conduct several individual studies (e.g. splitting the conceptual research model into several parts). It is also possible to reuse the conceptual research model as a whole to conduct new empirical research. Upgrading of the conceptual research model is another possibility, in addition to adding an international perspective, which would allow for cross-national comparison. We also see possibilities of further research in longitudinal studies as well as using perception theory (e.g. self-perception theory). Finally, the choice from among the different methodological approaches should be mentioned (e.g. the use of SEM, which makes it possible to investigate indirect effects).

\section{References}

1. Acs, Z. J., Audretsch, D. B., Braunerhjelm, P., \& Carlsson, B. (2009). The Knowledge Spillover Theory of Entrepreneurship. Small Business Economics, 32 (1), 15-30. http://doi.org/10.1007/ s11187-008-9157-3

2. Ajzen, I. (2005). Attitudes, personality and behavior. Maidenhead (England): McGraw-Hill/Open University Press.

3. Audretsch, D. B., Grilo, I., \& Thurik, A. R. (2007). Explaining entrepreneurship and the role of policy: a framework. The handbook of research on entrepreneurship policy, Cheltenham: Edward Elgar Publishing Limited.

4. Autio, E., Keeley, R., Klofsten, M., Parker, G., \& Hay, M. (2001). Entrepreneurial intent among students in Scandinavia and in the USA. Enterprise and Innovation Management Studies, 2 (2), 145-160. http://doi.org/10.1080/14632440110094632

5. Bacigalupo, M., Kampylis, P., Punie, Y., \& Van den Brande, L. (2016). EntreComp: The Entrepreneurship Competence Framework. EUR 27939 EN. Luxembourg (Luxembourg): Publications Office of the European Union; 2016. JRC101581. http://doi.org/10.2791/160811

6. Bird, B. (2019). Reflection on Entrepreneurial Competency, Katz, J.A. and Corbet, A.C. (Ed.) Seminal Ideas for the Next Twenty-Five Years of Advances (Advances in Entrepreneurship, Firm Emergence and Growth, Vol. 21), Emerald Publishing Limited, 133-140. https://doi. org $/ 10.1108 /$ s1074-754020190000021005

7. Bonesso, S., Gerli, F., Pizzi, C., \& Cortellazzo, L. (2018). Students' Entrepreneurial Intentions: The Role of Prior Learning Experiences and Emotional, Social, and Cognitive Competencies. Journal of Small Business Management, 56 (1), 215-242. https://doi.org/10.1111/jsbm.12399

8. Bosma, N., Hill, S., Ionescu-Somers, A., Kelley, D., Levie, J., \& Tarnawa, A. (2020). Global Entrepreneurship Monitor 2019/2020 Global Report. Global Entrepreneurship Research Association, London Business School. 
9. Boyatzis, R. E. (2011). Managerial and leadership competencies: A behavioral approach to emotional, social and cognitive intelligence. Vision, 15 (2), 91-100. https://doi. org $/ 10.1177 / 097226291101500202$

10. Cera, G., Mlouk, A., Cera, E., \& Shumeli, A. (2020). The Impact of entrepreneurship Education on Entrepreneurial Intention. A Quasi-Experimental Research Design. Journal of Competitiveness, 12 (1), 39-56. https://doi.org/10.7441/joc.2020.01.03

11. Curth, A., Chatzichristou, S., Devaux, A., \& Allinson, R. (2015). Entrepreneurship education: a road to success. A compilation of evidence on the impact of entrepreneurship education strategies and measures. Belgium: European Commission. http://doi.org/10.2769/408497

12. European Commission. (2013). Communication from the Commission to the European parliament, the Council, the European economic and social committee and the Committee of the regions. Entrepreneurship 2020 action plan. Reigniting the Entrepreneurial Spirit in Europe. https://eur-lex.europa.eu/legalcontent/EN/TXT/?uri=CELEX:52012DC0795.

13. European Commission. (2016). Communication from the Commission to the European parliament, the Council, the European economic and social committee and the Committee of the regions. A new skills agenda for Europe. Working together to strengthen human capital, employability and competitiveness. https://eur-lex.europa.eu/legal-content/EN/ TXT/?uri=CELEX\%3A52016DC0381

14. Franke, N., \& Lüthje, C. (2004). Entrepreneurial intentions of business students-A benchmarking study. International Journal of Innovation and Technology Management, 1 (3), 269-288. https://doi.org/10.1142/s0219877004000209

15. Fretschner, M., \& Weber, S. (2013). Measuring and understanding the effects of entrepreneurial awareness education. Journal of Small Business Management, 51 (3), 410-428. http://doi.org/10.1111/jsbm.12019

16. Gelderen, M. van, Brand, M., Praag, M. van, Bodewes, W., Poutsma, E., \& Gils, A. van. (2008). Explaining entrepreneurial intentions by means of the theory of planned behaviour. Career Development International, 13 (6), 538-559. http://doi.org/10.1108/13620430810901688

17. Godin, K., Clemens, J., \& Veldhuis, N. (2008). Measuring Entrepreneurship: Conceptual Frameworks and Empirical Indicators. Canada: Fraser Institute.

18. Heuer, A., \& Liñán, F. (2013). Testing alternative measures of subjective norms in entrepreneurial intention models. International Journal of Entrepreneurship and Small Business, 19 (1), 35-50. http://doi.org/10.1504/IJESB.2013.054310

19. Izquierdo, E., \& Buyens, D. (2008). Impact Assessment of an Entrepreneurship Course on Students' Entrepreneurial Competencies: A Constructivist Perspective. International Advances in Economic Research, 14, 395-406.

20. Küttim, M., Kallaste, M., Venesaar, U., \& Kiis, A. (2014). Entrepreneurship Education at University Level and Students' Entrepreneurial Intentions. Procedia - Social and Behavioral Sciences, 110, 658-668. http://doi.org/10.1016/j.sbspro.2013.12.910

21. Kyndt, E., \& Baert, H. (2015). Entrepreneurial competencies: Assessment and predictive value for entrepreneurship. Journal of Vocational Behavior, 90, 13-25. http://doi.org/10.1016/j. jvb.2015.07.002 
22. Lau, T. L., Shaffer, M. A., Chan, K. F., \& Man, T. W. Y. (2012). The entrepreneurial behaviour inventory: A simulated incident method to assess corporate entrepreneurship. International Journal of Entrepreneurial Behavior \& Research, 18 (6), 673-696. https://doi. org/10.1108/13552551211268120

23. Lackéus, M. (2015). Entrepreneurship in education. What, why, when, how. Retrieved from: https://www.oecd.org/cfe/leed/BGP_Entrepreneurship-in-Education.pdf

24. Liñán, F., \& Fayolle, A. (2015). A systematic literature review on entrepreneurial intentions: citation, thematic analyses, and research agenda. International Entrepreneurship and Management Journal, 11 (4), 907-933. http://doi.org/10.1007/s11365-015-0356-5

25. Liñán, F., \& Chen, Y. W. (2009). Development and Cross-Cultural Application of a Specific Instrument to Measure Entrepreneurial Intentions. Entrepreneurship Theory and Practice, 33 (3), 593-617. http://doi.org/10.1111/j.1540-6520.2009.00318.x

26. Lo, C.T. (2011). The impact of entrepreneurship education on entrepreneurial intention of engineering students. Doctoral dissertation, City University of Hong Kong.

27. Man, T. W. Y. (2012). Developing a behaviour-centred model of entrepreneurial learning. Journal of Small Business and Enterprise Development. 19 (3), 549-566. https://doi. org/10.1108/14626001211250289

28. Marques, C.S., Ferreira, J.J., Gomes, D.N., \& Rodrigues, R.G. (2012). Entrepreneurship education. How psychological, demographic and behavioural factors predict the entrepreneurship intention. Education + Training, 54 (8/9), 657-672. http://doi. org/10.1108/00400911211274819

29. Mitchelmore, S., \& Rowley, J. (2010). Entrepreneurial competencies: a literature review and development agenda. International journal of entrepreneurial Behavior \& Research, 16 (2), 92-111. http://doi.org/10.1108/13552551011026995

30. Moberg, K., Vestergaard, L., Fayolle, A., Redford, D., Cooney, T., Singer, S., \& Filip, D. (2014). How to assess and evaluate the influence of entrepreneurship education: A report of the ASTEE project with a user guide to the tools. The Danish Foundation for EntrepreneurshipYoung Enterprise.

31. Oosterbeek, H., van Praag, M., \& Ijsselstein, A. (2010). The impact of entrepreneurship education on entrepreneurship skills and motivation. European Economic Review, 54 (3), 442-454. http://doi.org/10.1016/j.euroecorev.2009.08.002

32. Oosterbeek, H., van Praag, M. van, \& Ijsselstein, A. (2008). The Impact of Entrepreneurship Education on Entrepreneurship Competencies and Intentions: An Evaluation of the Junior Achievement Student Mini-Company Program. IZA Discussion, 3641.

33. Rae, D. (2014). Graduate Entrepreneurship and Career Initiation in the 'New Era' Economy. Journal of General Management, 40 (1), 79-95. https://doi.org/10.1177/030630701404000105

34. Reyes, G. U., Mariano, R. A., Herrera, M. N. Q., Manipol, N. E. P., \& Cabardo, J. J. S. (2018). Personal Entrepreneurial Competencies and Entrepreneurial Intention of NonBusiness Students Enrolled in an Introductory Entrepreneurship Course. Journal of Economics, Management \& Agricultural Development, 4 (1), 93-102. 
35. Rideout, E. C., \& Gray, D. O. (2013). Does entrepreneurship education really work? A review and methodological critique of the empirical literature on the effects of university-based entrepreneurship education. Journal of Small Business Management, 51 (3), 329-351. http://doi. org/10.1111/jsbm.12021

36. Roy, R., Akhtar, F., \& Das, N. (2017). Entrepreneurial intention among science \& technology students in India: extending the theory of planned behavior. International Entrepreneurship and Management Journal, 13 (4), 1013-1041. http://doi.org/10.1007/s11365-017-0434-y

37. Sampedro, I. R., Fernández-Laviada, A., \& Herrero Crespo, A. (2014). Entrepreneurial intention: perceived advantages and disadvantages. Academia Revista Latinoamericana de Administración, 27 (2), 284-315. http://doi.org/10.1108/ARLA-09-2013-0144

38. Sánchez, J. C. (2011). University training for entrepreneurial competencies: Its impact on intention of venture creation. International Entrepreneurship Management Journal, 7, 239-254. http://doi.org/10.1007/s11365-010-0156-x

39. Sánchez, J. C. (2013). The impact of an entrepreneurship education program on entrepreneurial competencies and intention. Journal of Small Business Management, 51 (3), 447-465. http://doi.org/10.1111/jsbm.12025

40. Schøtt, T., Kew, P., \& Cheraghi, M. (2015). Future Potential. A GEM perspective on youth entrepreneurship 2015. Retrieved from: https://youtheconomicopportunities.org/sites/ default/files/uploads/resource/gem-2015-youth-report-1436523546.pdf

41. Serida Nishimura, J., \& Morales Tristán, O. (2011). Using the theory of planned behavior to predict nascent entrepreneurship. Academia, Revista Latinoamericana de Administración, 46, 55-71.

42. Souitaris, V., Zerbinati, S., \& Al-Laham, A. (2007). Do entrepreneurship programmes raise entrepreneurial intention of science and engineering students? The effect of learning, inspiration and resources. Journal of Business Venturing, 22 (4), 566-591. http://doi.org/10.1016/j. jbusvent.2006.05.002

43. Urbano, D., Aparicio, S., \& Audretsch, D. B. (2019). The effect of entrepreneurial activity on economic growth. In Institutions, Entrepreneurship, and Economic Performance, 85-106. http://doi.org/10.1007/978-3-030-13373-3_4

44. Veciana, J. M., Aponte, M., \& Urbano, D. (2005). University students' attitudes towards entrepreneurship: a two countries comparison. International Entrepreneurship and Management Journal, 1, 165-182. http://doi.org/10.1007/s11365-005-1127-5

45. Volery, T., Müller, S., Oser, F., Naepflin, C., \& Rey, N. del. (2013). The impact of entrepreneurship education on human capital at upper-secondary level. Journal of small business management, 51 (3), 429-446. http://doi.org/10.1111/jsbm.12020

46. Von Graevenitz, G., Harhoff, D., \& Weber, R. (2010). The effects of entrepreneurship education. Journal of Economic Behavior \& Organization, 76 (1), 90-112. http://doi.org/10.1016/j. jebo.2010.02.015

47. Zdolšek Draksler, T., \& Širec, K. (2018). Conceptual research model for studying students' entrepreneurial competencies. Naše gospodarstvo/Our economy, 64 (4), 23-33. https://doi. org/10.2478/ngoe-2018-0020 
Contact information

Tanja Zdolsek Draksler, Ph.D.

Jožef Stefan Institute

Centre for Knowledge Transfer in IT

Slovenia

E-mail:tanja.zdolsek@ijs.si

ORCID: 000-0002-6782-6275

prof. Karin Sirec, Ph.D.

University of Maribor

Faculty of Economics and Business

Institute for Entrepreneurship and Small Business Management

Slovenia

E-mail:karin.sirec@um.si

ORCID: 0000-0003-4191-5170 